\title{
Current Use and Potential for Implementing Forest Management Practices in Intensive Forest Management in the U.S.A. ${ }^{1}$
}

by

\author{
James L. Stewart ${ }^{2}$
}

\begin{abstract}
Pests annually cause immense damage. To reduce these losses, foresters need to manage forests and use available pest control technology. Today, we have the means but are restricted by economic, political, and public pressures. These pressures will continue to influence how we manage. As wood products come from a shrinking land base and resource values climb, pest losses will be less tolerable; yet restrictions, such as legislation and litigation, will limit needed forest and pest management.
\end{abstract}

\section{Résumé}

Les ravageurs causent d'immenses dommages annuellement. Afin de réduire ces pertes, les forestiers doivent aménager les forêts et utiliser la technologie disponible de lutte contre les ravageurs. Aujourd'hui, nous possédons les moyens de contrôle mais nous sommes restreints par des pressions d'ordres public, économique et social. Ces pressions continuerons à influencer notre façon de gérer. Comme les produits du bois proviennent de ressources de base qui diminuent avec une valeur de ces dernières qui augmentent, les pertes dues aux déprédateurs seront de moins en moins tolérables; encore que des restrictions, quelles soient d'ordres législatifs ou litigieuses, limiteront l'aménagement des forêts et contre les ravageurs.
Foresters manage the nation's forest resource to meet the needs of our society. So the actions of the forester, not those of the entomologist or pathologist, prevent or reduce pest-caused damages.

These losses are immense. Estimates of annual insect and disease losses exceed several hundred million dollars. Stated another way, yearly unsalvaged insect and disease volume losses are 2.4 billion cubic feet $\left(67.9\right.$ million $\left.\mathrm{m}^{3}\right)$ or equivalent to about one-fourth of the nation's annual timber harvest. Reduced growth attributed to pests equals another quarter of the annual harvest. In forested areas, pests also depreciate the value of timber products, interfere with management plans and activities, reduce seed production, and prevent regeneration. In recreation areas, such as campgrounds, pests reduce forest cover and create tree hazards.

1Paper presented at the joint meeting of the Canadian Institute of Forestry and the Society of American Foresters in Quebec City, August 6-9, 1984. 2Director of Forest Pest Management, USDA Forest Service, P.O. Box 2417 Washington, DC 20013.

\section{Pest Losses are Staggering}

The aggregate estimates of pest losses are as staggering as the scope of the outbreaks that cause these losses.

During 1983, for example, the gypsy moth defoliated about 2.4 million acres (971 280 ha). The moth now infests an area extending from Maine south into northern Virginia. In the Northeast that same year, defoliation by a second insect, the spruce budworm, topped the 6 -million-acre mark (2.4 million ha.). In the South, fusiform rust infection occurs on at least 10 percent of the pines growing over 14 million acres (5.7 million ha). And in the West, mountain pine beetle outbreaks extend over 3.5 million acres ( 1.4 million ha); each year, dwarf mistletoe-caused losses exceed 300 million cubic feet ( 8.5 million $\mathrm{m}^{3}$ ) over 22 million acres ( 8.9 million ha).

Under these circumstances, we cannot protect every tree, avoid every outbreak, or reduce all losses to tolerable levels. We can, however, focus our attention on protecting some stands and sites.

Because of the overwhelming size of these pest outbreaks, we must focus the bulk of our pest management effort on the nation's high-value, managed forests. Many econo- 
mists suggest that our timber base is shrinking. As more of that ever-shrinking timber base becomes intensively managed to satisfy future roundwood product needs, greater emphasis must be placed on protecting the resource.

\section{How Do We Reduce These Losses?}

To prevent or reduce pest-caused losses, we should incorporate the principles of integrated pest management into our ongoing resource management activities.

Integrated pest management, an often-used, muchabused term, describes an approach that involves comprehensive decision making and action to control pests effectively, economically, and in an environmentally acceptable manner. Using this approach we can identify control strategies, both prevention and suppression, that will work best on a specific site. Then, we can translate our decision into action.

In addition, one kind of pest may influence the damage of another. As we learn about these pest complexes we have become more aware of a spectrum of potentially destructive organisms. The interdependence of pest organisms complicates the job of developing forest pest management control technology and incorporating it into management plans and operations. Computer-based decision keys, developed in the South and in the Pacific Northwest, are examples of our first attempts to use computer technology to help foresters decide how to deal with the effects of multiple pests.

\section{The Realities of Forest Management}

We have come a long way toward better integrating forest pest management practices into resource management activities. Three factors have strongly influenced this process.

1. Pest management technology, that is, understanding how pest populations, forest ecosystems, and resource management activities interact, as well as using effective, economical, and environmentally sound pest management strategies.

2. The intensity of forest management.

3. The degree to which forest managers incorporate pest considerations into resource planning and management activities.

\section{Pest Management Technology}

Over the past decade, our understanding of the interaction between pest populations, forest ecosystems, and resource management activities has increased substantially. Though still incomplete, this understanding has enabled us to develop a number of stand growth projection models and forest pest models. Using these models, we can estimate growth both with and without the effects of pests. And as a result of the planning required by the Forest and Rangeland Renewable Resources Planning Act and the National Forest Management Act, we now have more complete inventory data to use in programming the models.

Equally encouraging is our better understanding of pesthost interactions. We have, for example, management strategies to make pine stands less susceptible to bark beetle attack by altering the stocking density. We believe the spruce budworm threat can be lowered by reducing the percentage of balsam fir in mixed spruce-fir stands. In the South, we are planting rust resistant stock to reduce the damage from fusiform rust; and when we regenerate certain conifer stands in the West, we are removing infected overstory trees so that the dwarf mistletoe seeds do not rain down and infect the new stand.

We understand some of the impacts of competing vegetation on tree growth and have some alternatives for costeffective treatment. We have improved technology for applying chemical and biological pesticides and for using natural and synthetic sex attractants to monitor incipient insect populations so that we can intervene, if necessary.

We have the knowledge and the technology to prepare silvicultural prescriptions that reduce the risk of some pest outbreaks. Today, many resource managers are using this information. All too often, however, pest management technology is ignored or only superficially considered.

\section{Intensity of Management}

Intensive forest management, such as silvicultural treatments to regulate stocking, age, species and genetic composition, opens many avenues for applying integrated pest management. Intensive forest management also means that pesticides can be applied in a more precise and timely fashion, so they are more effective and a smaller area can be treated. In addition, early detection of pest problems is more likely in intensively managed forests. When pest problems are detected earlier, we have greater latitude in considering control alternatives. Techniques like pheromones, parasites and predators, biological pesticides, and sanitation thinning work better when pest populations are small. Also, trees in intensively managed forests are basically healthy. When outbreaks do occur, the trees' natural resistance to some pests, which thrive on weakened trees, makes control more feasible.

The forces that drive the degree or intensity of forest management include the public's demand for forest products, the availability of markets, our access into the forests, the funding for management, and the public's acceptance of that management. These economic, political, and public pressures limit our ability to manage the forests and, consequently, our management of forest pests.

When forest management practices are limited, full implementation of pest prevention - or more broadly speaking, integrated pest management - is also limited. We have many examples in the South of devastating southern pine beetle outbreaks occurring in unmanaged, overmature pine stands. These effects have been documented in some stands that were set aside as proposed wilderness areas, in which there was no opportunity to take preventive action. The beetle changed the character of these stands from stately, overmature pine to scrub oak and other hardwoods.

Pest management is also curtailed in many parts of the Rocky Mountains, even though those areas have large pine beetle and spruce budworm outbreaks. The forests would be less susceptible if they were thinned; however, many stands are too far from current markets to be harvested economically or lack access or both. The cost of building roads and the relatively low timber values make administrators and landowners reluctant to invest funds for noncommercial silvicultural treatment. In addition, many of these areas are now in or are under consideration for wilderness designation or in other legal designations that restrict management.

I often hear strong pro-integrated pest management positions advocated by people who also favor restricting tree 
harvest and road construction. The cause-and-effect relationship between forest management and pest management eludes them. Where we cannot practice forest management - where we cannot harvest, thin, treat competing vegetation, or use pesticides - we cannot fully practice integrated pest management. If we are going to reduce pest losses, we must strive to reduce this type of misunderstanding.

\section{Responsibilities of Forest Managers}

Are forest managers incorporating pest considerations into resource planning and management operations? Somewhat! We have begun to change the historical notion that entomologists, pathologists, and other pest specialists - not the forester - are responsible for preventing and suppressing damaging pest outbreaks.

Attitudes are changing because troublesome pest outbreaks cannot be ignored. Also, we know more about the silvicultural practices that can reduce the threat or severity of pest outbreaks, and we are using new computer models to predict the consequences of pest outbreaks. Together, these technological improvements have helped convince many foresters that preventive treatments are worthwhile.

Another consideration is public pressure, which has resulted in federal laws that mandate a complete assessment of the social, economic, and biological risks and benefits. Forest managers can no longer ignore conditions that favor pest buildup expecting to take direct control action when an outbreak eventually occurs. Therefore, foresters must give more complete consideration to pests in forest management planning and its implementation.

\section{But we still have a long way to go.}

\section{Outlook}

Because forest resource values and management costs will climb, we shall, of necessity, become more sensitive to those influences that disrupt management plans and production goals. Forest managers will have to consider the potential effects of pests and mitigating options. Pest damage in intensively managed forests will be less tolerable.
At the same time, intensive forest management offers the forester the capability to implement integrated pest management. Being able to intensively manage the forest allows the forester to practice prevention and enhances the use of improved pest management tactics, such as pheromones, augmentation of predators and parasites, and sanitationharvest, in a total integrated strategy.

I see, however, the trend toward more and more restrictions on forest management continuing. I also do not see the pesticide issue being solved very soon. Therefore, this aspect of pest management will remain quite restricted and, in some places, prohibited.

Professional foresters will have to face the dilemma caused by the restrictions. On one hand, the public will demand that they control tree-killing pests. At the same time, foresters will not be allowed to practice integrated pest management because of the restrictions on intensive forest management.

To summarize, the potential for implementing integrated pest management in intensive forest management is improving. To realize this potential, however, we must apply our knowledge, the public must be aware of the relationship between pest management and forest management, and foresters must realize their responsibilities. Foresters must consider how pests will affect or are affected by alternative management options and must apply appropriate pest prevention suppression means wherever they have the opportunity to intensively manage the forest.

\section{Who decides which stands will be protected?}

The need and opportunity for applying effective integrated pest management strategies are largely determined by resource management objectives and decisions. Therefore, forest managers are responsible (1) for considering how pests will affect or are affected by alternative management options and (2) for applying appropriate pest management prevention and suppression measures in operational resource management activities. 